\title{
EXTRACELLULAR MIMETICS: A COMPARATIVE EVALUATION OF CELL ENCAPSULATION UTILIZING HYDROGELS AND SCAFFOLDS
}

\section{Marco Antonio Vieira Macedo Grinet ${ }^{1}$ \\ Thiago Moreira Pedroso ${ }^{2}$ \\ Fernanda Roberta Marciano ${ }^{3}$}

Resumo: An in vitro encapsulation platform utilizing hydrogels and bone matrix (BM) scaffolds to investigate the effects of microenvironmental parameters on encapsulated goat mesenchymal stem cells (gMSC) was presented. The base encapsulation matrix was composed of a biocompatible hydrogel formed through a photoinitiated polymerization process. Different polymer concentrations were used to compare the effects of hydrogel crosslinking density on physical properties, as well as on cell viability. The potential of BM to support the growth and differentiation of gMSC was also analyzed. Both methods were compared in order to analyze viability. Structures that better allow flow of oxygen showed more promising results, whereas BM structures require a better evaluation method for concrete results.

Palavras-chave: Cell Culture; gMSC; Bone Matrix; Hydrogel; Cell Encaps.

\footnotetext{
${ }^{1}$ Engenharia Biomédica/Universidade do Vale do Paraíba, Brasil. E-mail: mgrinet1@gmail.com.

${ }^{2}$ Engenharia Biomédica/Universidade do Vale do Paraíba, Brasil. E-mail: thiagompedroso@gmail.com.

${ }^{3}$ Engenharia Biomédica/Universidade do Vale do Paraíba, Brasil. E-mail: frmarciano@univap.br.
} 